\title{
Stakeholder Role in Improving Agribusiness Efficiency and Food Security in Developing Countries
}

\begin{abstract}
Submitted 21/07/19, $1^{\text {st }}$ revision 13/09/19, $2^{\text {nd }}$ revision 20/10/19 accepted 16/11/19
\author{
Sri Rahayu ${ }^{1}$, Waridin ${ }^{2}$, Purbayu Budi Santoso ${ }^{3}$, Izza Mafruhah ${ }^{4}$
}

Abstract:

Purpose: Food security is one of the main goals for sustainable development having an important position in determining the government policies. The main objective of this study is to analyze the role of stakeholders in corn farming business efficiency by 1) analyzing the efficiency of small-scale corn farming in Grobogan Regency, Central Java and 2) analyzing the role of stakeholders in increasing food security.

Design/methodology/approach: The study used a mixed method, a combination of quantitative and qualitative analysis. The analytical tool used was Data Envelopment Analysis (DEA), regression analysis, and stakeholder analysis with a focus on convergence and divergence among stakeholders.

Findings: The calculation results show that as many as 18 (30\%) corn farming has been efficient. The main stakeholders' role was found between the Agriculture office and farmers' associations.

Practical implications: The results show a close relationship and communication among actors. Furthermore, the actors share the same objectives so that the convergence path is mutually supportive and synergistic.

Originality/value: The study provides a new discourse in an effort to improve agricultural efficiency in developing countries by analyzing the closeness between actors and modeling farmers' access to agricultural resources and governance.
\end{abstract}

Keywords: Efficiency, DEA, stakeholder, farming business.

JEL code: G34.

Paper type: Research article.

\footnotetext{
${ }^{l}$ Faculty of Economics and Business, Universitas Diponegoro Jl. Prof. Soedarto SH, Tembalang, Semarang, Central Java, Indonesia, email: sri_yayux@yahoo.co.id

${ }^{2}$ Faculty of Economics and Business, Universitas Diponegoro Jl. Prof. Soedarto SH, Tembalang, Semarang, Central Java, Indonesia.

${ }^{3}$ Faculty of Economics and Business, Universitas Diponegoro Jl. Prof. Soedarto SH, Tembalang, Semarang, Central Java, Indonesia.

${ }^{4}$ Faculty of Economics and Business, Universitas Sebelas Maret, Surakarta, Indonesia.
} 


\section{Introduction}

Food security is an important part in improving people's welfare. Law No. 18 of 2012 concerning food security states that food administration is aimed at fulfilling basic human needs in a fair, equitable and sustainable manner based on food sovereignty, food self-reliance, and food security (OECD, 2012; USAID/United States Agency for International Development, 2011). Fulfillment of food consumption needs to prioritize domestic production by optimally utilizing local resources and wisdom. To realize this, the three main principles considered are food availability, food affordability and food use or consumption (Widayati, Waridin, \& Mafruhah, 2019; AAFC/Agriculture and Agri-Food Canada, 2004; UNIDO (United Nations Industrial Development Organization), 2009).

In Indonesia, corn is one of the strategic agricultural commodities because it can potentially support food security (Ariani, 2016) and increase farmer income/welfare (Leki et al., 2016). In terms of food security, corn can be consumed directly as a staple food other than rice or as an ingredient of processed food products (Ariani, 2016). Corn commodities (leaves and seeds) are also needed as animal feed which indirectly supports the supply of animal protein for the community (Tangendjaja et al., 2016). Food using corns also varies, corn seeds, young corn, corn bran, broken corn, and cornstarch. In addition to becoming ready-made food, corn is also used as raw material for food and non-food industries, both produced by home industry, small industry, and medium and large-scale modern industry. Household industries are generally located in rural areas, while medium and large industries are located in the suburbs with adequate facilities and infrastructure (Suryana and Agustian, 2016).

Corn production centers in Indonesia are generally dryland agriculture, rainfed agriculture, and have high poverty rates (Food Security Agency, 2015). However, in recent years maize has begun to be cultivated in irrigated lands in several areas in and outside Java. Approximately 59\% of corn cultivation in Indonesia is carried out on dry land (Kasryno et al., 2008) with a narrow arable land area (on average of only $0.3 \mathrm{ha} /$ farmer). In comparison, corn farmers in developed countries such as the United States (Tangendjaja, 2016) generally cultivate in extensive arable land (on average of $190 \mathrm{ha} /$ farmer) and they are supported by modern financing and agricultural practices (seeds, cropping patterns, mechanization of land processing, post harvesting, stock management, market information and climate and soil analysis) and short value chains.

The survey by Kasryno et al. (2008) in 418,000 household samples found that the average income of farmer households was $\mathrm{Rp} 2.2$ million per month or $\mathrm{Rp} 550,000$ per capita per month (assuming the average number of household members was four persons). The average income is actually two times higher than the rural poverty line of Rp. 286,000. Some literature has discussed corn farming (Kasryno et al., 2008; Tangendjaja, 2016; Timmer, 1987; Swastika, 2002), but only few studies have compared corn farming based on type of land ownership (tenant farmers, owner- 
tenant farmers, landlord farmers, sharecroppers). These differences can affect the characteristics of resource access and governance. The study was conducted by surveying 100 corn farmers in Grobogan, Central Java, Indonesia to analyze stakeholder role in improving agribusiness efficiency and food security.

\section{Materials and Methods}

The research object was hybrid corn cultivated for animal feed. Data was processed and analyzed with Data Envelopment Analysis (DEA) (Cooper et al., 2000). Input variables in this study were labor costs, seeds, fertilizers, insecticides, and land rent. The level of efficiency of corn farming is defined as the ratio between total weighted output and total weighted input. The criteria used to assess the efficiency of corn farming was technical efficiency. Technical efficiency was obtained from the ratio of output to the input produced. The efficiency value was the ratio of input to output ranging from 0 to $1(0 \%-100 \%)$. The data used in this study can be seen in Table 1 processed using DEA. To determine the effect of governance on the efficiency of corn farming, the following multiple linear regression analysis was used:

$$
\begin{aligned}
\mathrm{YY}^{\prime}= & \delta_{0}+\delta_{1} \mathrm{SIZE}+\delta_{2} \mathrm{OWN}+\delta_{3} \mathrm{FET}+\delta_{1} \mathrm{TRAC}+\delta_{2} \mathrm{IRIG}+\delta_{3} \mathrm{SAL} 1+\delta_{1} \mathrm{SAL} 2+ \\
& \delta_{2} \mathrm{SAL} 3+\varepsilon
\end{aligned}
$$

where: $\mathrm{YY}^{\prime}=$ Corn Farming Efficiency; SIZE = Size of Farmland $(1=<0,25 \mathrm{Ha}, 2$ $=0,25 \mathrm{Ha}-1 \mathrm{Ha}, 3=>1 \mathrm{Ha}) ; \mathrm{OWN}=$ Land Ownership $(1=$ farm laborer/tenant farmers, 2 = sharecroppers, 3 = owner-tenant farmers); FET = Seed Technology Access $(1=$ Superior seed, $0=$ local seed $) ;$ TRAC $=$ Land Processing Technology Access $(1=$ Tractor, $0=$ no $)$; IRIG $=$ Irrigation Access $(1=$ technical $/$ semi-technical irrigation, $0=$ no); SAL1 = 1st Marketing Channel $(1=$ sold to village traders, $0=$ other); SAL2 = 2nd Marketing Channel ( $1=$ sold to subdistrict traders, $0=$ other $)$; SAL3 $=3$ rd Marketing Channel $(1=$ sold to cooperatives, $0=$ other $) ; \delta=$ intercept and slope; $\varepsilon=$ Error term.

\section{Results and Discussion}

\subsection{Data Description}

Hybrid corn is a type of corn that is widely cultivated by farmers in Grobogan regency. The cost of corn farming is classified into labor costs, production facility costs and other costs. The amount of labor use can be known from the results of interviews with corn farmers (Table 1). Labor costs consist of labor for pre-harvest, harvest, and post-harvest. Pre-harvest activities include nurseries, soil preparation, planting, fertilizing, weeding (once), and controlling pests and plant diseases (2 times). Post-harvest activities include harvesting, threshing, cleaning, transporting, drying and storing. Workers come from family members and hired labor from outside the family. Wage labor from outside the family is often calculated and is a real cost, while family labor is not a real cost incurred by farmers. 
Table 1. Total Costs for Hybrid Farming (Rp)

\begin{tabular}{|l|c|c|c|c|c|c|c|c|c|}
\hline \multirow{3}{*}{ Costs } & \multicolumn{9}{|c|}{ Types of Farmer } \\
\cline { 2 - 11 } & \multicolumn{3}{|c|}{ Tenant } & \multicolumn{3}{c|}{ Owner-Tenant } & \multicolumn{3}{c|}{ Sharecroppers } \\
\cline { 2 - 11 } & Mean & Min & Max & Mean & Min & Max & Mean & Min & Max \\
\hline Labor & 706.7 & 318 & 1845 & 713.3 & 366 & 1845 & 1640.5 & 792 & 3660 \\
\hline $\begin{array}{l}\text { Production } \\
\text { Facilities }\end{array}$ & 986.6 & 519.8 & 2599 & 1089.8 & 419.8 & 2499 & 2212.9 & 1039.6 & 5198 \\
\hline Total Costs & 1693.2 & 837.8 & 4444 & 1803.1 & 785.8 & 4344 & 3853.4 & 1831.6 & 8858 \\
\hline
\end{tabular}

Source: Interview with Farmers (2017).

Revenue from total farming is the product of multiplication of farm production at a price per unit. Corn farming in various types of ownership and marketing purposes obtained $\mathrm{R} / \mathrm{C}$ ratio above 1 and a positive $\mathrm{B} / \mathrm{C}$ ratio which shows that corn farming provides economic benefits. The $\mathrm{R} / \mathrm{C}$ ratio above 1 means that corn farming income is always greater than the cost and a positive $\mathrm{B} / \mathrm{C}$ ratio means that corn farming is profitable. The highest $\mathrm{R} / \mathrm{C}$ ratio and $\mathrm{B} / \mathrm{C}$ ratio was found in sharecroppers followed by owner farmers, tenant farmers, and owner-tenant farmers. The $\mathrm{R} / \mathrm{C}$ ratio and $\mathrm{B} / \mathrm{C}$ ratio for farmers who sell to cooperatives was generally greater than farmers selling to PPD (Collector Traders at Village level) and PPK (Collector Traders at Subdistrict level) because of higher selling prices. However, farmers rarely sell to cooperatives because: 1) not all farmers are members of cooperatives or farmers' associations (KUD, Gapoktan, LMDH), 2) cooperatives generally buy corn with payment tempo, i.e. paying to farmers after being paid by the cooperative partners' factories, while farmers need cash funds, 3) farmers located in rural areas, the distance to the cooperatives, which is generally in the capital city of the sub-district, makes them choose more accessible sales (to PPD) (Trihatmoko, 2019; Suparnyo, 2019).

\subsection{DEA Analysis}

Analysis of input and output data with DEA results in the efficiency of corn farming is presented in Figure 1 and Table 2. Figure 1 shows that most $(86.49 \%)$ of corn farming in Central Java, Indonesia has an efficient performance, with efficiency levels ranging from $80 \%-100 \%$. Only $11.71 \%$ of corn farming is in the efficiency of $60 \%-80 \%$ and only $1.8 \%$ of LKMA (Agribusiness Microfinance Institution) has an efficiency of less than $60 \%$.

\subsection{Regression Analysis}

The results of the regression equation factors that influence the efficiency of corn farming are obtained with F-test value 68.198 therefore the model is significant at an error rate of $1 \%$. The results of the regression equation show an R2 value of 0.934 which reflects that all independent variables are able to explain variations in change, namely an increase or decrease in the dependent variable (corn farming efficiency) of $93.4 \%$ (Table 3 ). 
Figure 1. Level of Corn Farming Efficiency

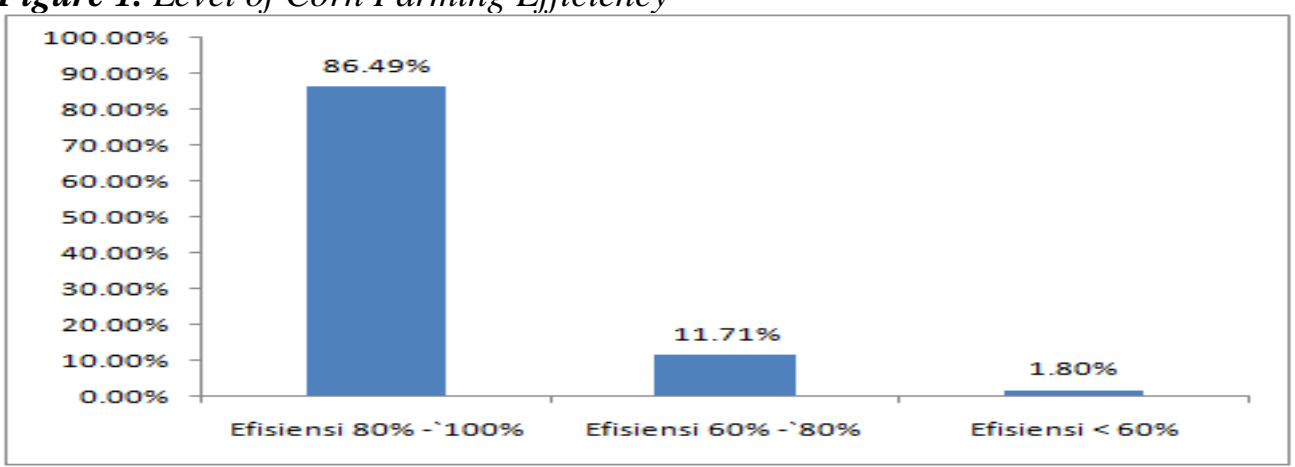

Table 2. Summary of DEA Analysis Results of Corn Farming Efficiency

\begin{tabular}{|l|c|c|}
\hline \multicolumn{1}{|c|}{ Parameters } & & Values (\%) \\
\hline Efficiency & & $88.63 \%$ \\
\hline Average Efficiency (\%) & & $0.93 \%$ \\
\hline Standard Deviation (\%) & & $58.88 \%$ \\
\hline Minimum Efficiency (\%) & & $100.00 \%$ \\
\hline Maximum Efficiency (\%) & & LKMA percentages (\%) \\
\hline \multicolumn{1}{|c|}{ Frequency } & Number of LKMA (n) & $86.49 \%$ \\
\hline Efficiency level 80\% -100\% & 96 & $11.71 \%$ \\
\hline Efficiency level 60\% - $80 \%$ & 13 & $1.80 \%$ \\
\hline Efficiency level <60\% & 111 & $100.00 \%$ \\
\hline Total & & \\
\hline
\end{tabular}

Source: Processed from Corn Farmers' survey data (2017).

Table 3. Summary regression analysis

\begin{tabular}{|l|c|c|}
\hline \multicolumn{1}{|c|}{ Independent Variable } & \multicolumn{2}{c|}{ LKMA efficiency } \\
\hline (Constant) & $\beta$ & $p$ \\
\hline Land area & 60341.000 & 0.000 \\
\hline Land Ownership & 0.845 & $* * *) 0.004$ \\
\hline Access to Seed Technology & 0.104 & 0.446 \\
\hline Access to Land Processing Technology & 1.118 & $* * *) 0.007$ \\
\hline Irrigation Access & -0.137 & 0.741 \\
\hline 1st Marketing Channel & 0.454 & $*) 0.086$ \\
\hline 2nd Marketing Channel & -0.361 & 0.297 \\
\hline 3rd Marketing Channel & -0.857 & $* * *) 0.002$ \\
\hline R-squared & 0.591 & $* *) 0.030$ \\
\hline F-statistic & 0.934 & \\
\hline Prob(F-statistic) & $68, .198$ & \\
\hline Note: ***) & 0.000 & \\
\hline
\end{tabular}

Note: ***) has a significant effect on the error rate of $1 \%, * *)$ has a significant effect on the error rate of $5 \%, *$ ) has a significant effect on the error rate of $10 \%$. 
The regression results show that six factors have a significant effect on the efficiency of corn farming. These factors are land size, land ownership, access to seed technology, access to land processing technology, irrigation access and marketing channels. The higher the width of the arable land, the higher the efficiency of corn farming. Farmers with ownership of their own land, using superior seeds, access to agricultural mechanization, access to irrigation and having direct market access have higher corn farming efficiency.

\subsection{Stakeholder Analysis}

This stakeholder analysis is used to formulate a management model that can accommodate all stakeholders' interests by taking into account the potential and the role that can be performed in the corn value chain in Grobogan Regency. There are 12 stakeholders involved: 1) owner farmers, 2) tenant farmers, 3) collector traders at village level (PPD), 4) collector traders at sub-district level (PPK), 5) wholesalers (PB), 6) animal feed factories, 7) corn SMEs and food services, 8) agriculture \& forestry services, 9) Gapoktan (farmers' association), 10) universities, 11) banking/financial institutions, 12) KUD/LMDH (cooperatives). The stakeholders' objectives are categorized into 6: price, distribution, risk, partnership, contracts, and producers' network. The net distance between the actors in presented in Figure 2.

Figure 2. Net distances between actors

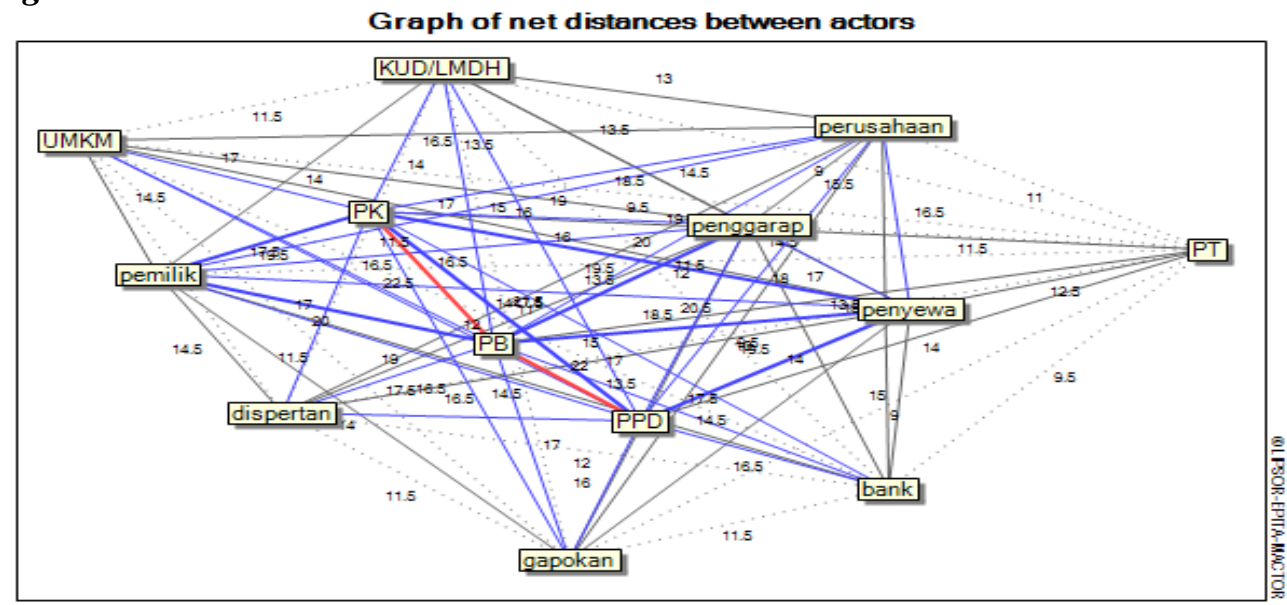

\footnotetext{
Shortest net distances

- Short net distances

- Moderate net distances

- Longest net distances
}

The results of stakeholder analysis show mapping between objectives. The network with the shortest distance is between partnerships and work contracts, risk and distribution, and distribution and partnerships. Moderate distance can be seen in the relationship between risk and network, network and contract, network and distribution, and network and partnership, while the longest distance is found in the relationship between network and price. 


\section{Conclusion}

This study revealed that the level of efficiency of corn farming varied between $76.84 \%$ - 104.18\%. Most (92.79\%) of corn farming in Central Java shows efficient performance, with efficiency levels ranging from $80 \%-100 \%$. Only $7.21 \%$ are in the efficiency of $<80 \%$. In short, an average of $89.37 \%$ can be categorized as efficient because the level of efficiency ranges from $80 \%-100 \%$. The results of stakeholder analysis show a close relationship and communication among actors. Furthermore, these actors share the same objectives so that the convergence path is mutually supportive and synergistic.

\section{References:}

AAFC (Agriculture and Agri-Food Canada). 2004. Value-added agriculture in Canada. Report of the standing senate committee on agriculture and forestry. Agriculture and Agri-Food, Canada.

Ariani, M. 2016. Direction, Constraints and Importance of Diversifying Food Consumption in Indonesia. In the Agro Economic Research Forum, 21(2), 99-112.

Cooper, W.W., Seiford, L.M. and Tone, K. 2000. Data envelopment analysis. Handbook on Data Envelopment Analysis, 1st ed., Cooper, W.W, Seiford, L.M, Zhu, J., Eds.

Food Security Agency. 2015. Technical Guidelines for Strengthening Community Food Distribution Institutions (Strengthening LDPM). Jakarta, Ministry of Agriculture.

Kasryno, F., Pasandaran, E., Suyamto and Adnyana, M.O. 2008. Corn Economic Overview of Indonesia, Jakarta, Indonesia. Agency Agricultural Research and Development.

Leki, S., Hanani, N., Dwiastuti, R. and Setiawan, B. 2016. Household Economic Decisions of Corn Farmers at West Timor, Indonesia. Current Agriculture Research Journal, 4(1), 74.

OECD. 2012. OECD Review of Agricultural Policies: Indonesia. OECD Publishing.

Suparnyo. 2019. Cooperatives in the Indonesian Constitution and the Role in Empowering Members: A Case Study. Journal of Legal, Ethical and Regulatory Issues, 22(3).

Suryana, A. \& Agustian, A. 2016 Analysis of the competitiveness of corn farming in Indonesia. E-journal of agricultural R\&D.

Swastika, D.K.S. 2002. Corn self-sufficiency in Indonesia: The past 30 years and future prospects. Journal of Agricultural Research and Development, Indonesia.

Tangendjaja, B., Rachmawati, S. and Wina, E. 2016. Economic analysis of demand for corn for feed. Indonesian Corn Economy. Jakarta, Agricultural Research Agency, Ministry of Agriculture.

Timmer, C.P. ed. 1987. The corn economy of Indonesia. Cornell University Press.

Trihatmoko, R.A. 2019. State-owned enterprises and economic constitutions: A case study of judicial review of Law No. 19 of 2003. Journal of Law and Justice, 8(1), 149-165.

USAID (United States Agency for International Development). 2011. Value chain analysis of off-season vegetables sub-sector in Nepal. Nepal Economic Agriculture, and Trade Activity. USAID general development office. Kathmandu, Nepal.

Widayati, T., Waridin, W. and Mafruhah, I. 2019. Between Environmental Performance and Agricultural Productivity: Assessing the Convergence and Divergence of DemandDriven Agricultural Extension. International Journal of Energy Economics and Policy, 9(4), 158-165. 